\title{
YOUTH CONTRIBUTIONS TO CHURCH GROWTH: A CASE STUDY OF THE LIGHT OF THE WORLD SOCIETY (LOWS) OF CHRIST APOSTOLIC CHURCH, NIGERIA, 1966 - 1992
}

\author{
Afolabi Samuel Oluseyi Ph.D. \\ He is the Senior Pastor of Christ Apostolic Church All Nations Assemblies, Ibadan, Nigeria Biographical \\ Sketch of the Author \\ AFOLABI, Samuel Oluseyi holds a Ph.D. in Religious Studies from the University of Ibadan, Nigeria. He is a \\ Lecturer in Church History, Church Planting and Growth at Michael Olowere College of Theology \\ (MOCOT), Ashi, Ibadan, Oyo State, Nigeria.
}

He is an alumnus and a lecturer of Missions and Exposure Training - MET (Pentecostal Assemblies of Canada), Pretoria, South Africa.

Article DOI: $\underline{\text { https://doi.org/10.36713/epra5210 }}$

\begin{abstract}
Christ Apostolic Church was the foremost African Indigenous Church in Nigeria and its history dates back to 1918. The growth and expansion of the church in Nigeria was aided by the activities of its youth organisations, foremost among which was the Light of the World Society. This article examines the origin of the society, its objectives, administration and programmes. The article also highlights the various contributions of the society to the growth and expansion of the church via evangelism and church planting, promotion of Christian education and leadership development. The study adopted George Ehusani's concept which states that the youths should not be seen as mere objects or targets of the Church's programmes and projects, rather they should be seen as active agents of evangelization. ${ }^{1}$ Data were gathered through the use of structured oral interview, questionnaire, archival materials and bibliographical search.
\end{abstract}

KEYWORDS: Christ Apostolic Church, Light of the World, Youths, Growth and Expansion

\section{INTRODUCTION}

Christ Apostolic Church was one of the African Indigenous Churches that started and had phenomenal growth particularly in Sub-Saharan Africa starting from the $19^{\text {th }}$ century till date. ${ }^{2}$ The Church started as an indigenous prayer group in 1918 and later went through many stages before it finally adopted its present name. ${ }^{3}$ The activities of the Light of The World Society ( Egbe Imole Aye), being one of the foremost youth associations in the church, contributed immensely to the growth and expansion of the church in Nigeria.

\section{THE EARLIEST YOUTH ORGANISATIONS}

The history of youth organisations in Christ Apostolic Church dates back to the 1930s when the Nigerian Apostolics and the white Apostolics from Britain were still in alliance. ${ }^{4}$ The youth society that emerged then operated under the leadership of I. Adesile (later Pastor) as Chairman, J. A. Ademakinwa (secretary) and Martin Sanda (Elder). ${ }^{5}$

The Society was formed for a number of purposes; to settle misunderstanding and disputes 
within the revival group; to advise the leaders of the group on church administration as found appropriate and expedient; to pray for the unity and progress of the Group; to give financial aids to indigent members of the church. ${ }^{6}$ However, the opposition that later arose against the group drove it underground.

In the 1940s - after the cleft within the group, fresh efforts were made by the youths to come together. First to emerge was the first Young men Christian League (YMCL).But as the body later became moribund, the C.A.C Youth Congress took its place towards late 40s. But like its predecessor, the congress was short-lived; hence, the resurgence later at Ebute Metta of the Y.M.C.L. Similarly, in the early 1950s, some C.A.C students and Youths at Oniyarin C.A.C Assembly at Ibadan established a virile Youth Association called the Christ Apostolic Progressive Union. Again, its activities however, soon fizzled out. ${ }^{7}$

\section{THE ORIGIN OF THE LIGHT OF THE WORLD (Egbe Imole Aye)}

The earliest youth organisation that was formerly and properly organised after the exit of the above named ones was the Light of the World Society. The Society came into existence in 1966 as a result of the merger of two groups, "The Praying Battalion" and "The Blessed Gospellers". 8 The society engaged mainly in fervent prayers, evangelism, revival and crusades targeted at church planting and spiritual revival of C.A.C members. The group actually engaged more in revival meetings and church planting during its years of existence. 9 Her motto was "Preach the Word".

\section{THE OBJECTIVES OF THE GROUP}

The following are the objectives of the group:

1. To labour assiduously for the physical and spiritual growth of the church through preaching and teaching the total truth of the Gospel.

2. To pursue the infilling of the Holy Ghost and his gifts.

3. To ensure the spiritual growth of all members as instruments of righteousness.

4. To teach, practise, uplift and protect Bible doctrines in line with the doctrines of the church.

5. To strengthen members in the faith so that they can become effective witnesses for Christ.

6. To regularly organise programmes that can enhance the spiritual growth of members.
7. To be an example to the believers in speech, in conduct, in love, in spirit, in faith and in holiness.

8. To be fervent in prayers, preaching and spiritual counselling for restoration of backsliders and salvation of sinners. ${ }^{10}$

\section{THE ADMINISTRATION OF THE LIGHT OF THE WORLD SOCIETY}

The Society was administered by the National Executive Committee made up of the National President, Vice President, General Secretary, Assistant General Secretary, Treasurer, Financial Secretary, Auditor, Publicity Secretary, Evangelism Secretary, Welfare Secretary, Development Secretary, Special Adviser and Patron. ${ }^{11}$ There were also State Executive Committees and Assembly Executive Committees. Its past officers included Elder late Pastor Fagbo (President), late Pastor M. D. Mogaji (Vice President), Elder Soneye (Gen. Secretary) and Chief D.F. Duduyemi (Treasurer). ${ }^{12}$

\section{THE PROGRAMMES AND ACTIVITIES OF THE LIGHT OF THE WORLD SOCIETY}

At the various levels, (National, State and Assembly), the programmes of the Society included regular prayer meetings, house to house/street evangelism and open - air gospel crusades. Others were Bible lectures, Annual Anniversaries and the annual General Rally which was rotated in different parts of the country during the last week of April. During the rallies, there were usually fervent prayer sessions, evangelistic outreaches and Bible teachings which laid emphasis on godliness, rededication and commitment to Christian virtues and services. ${ }^{13}$

\section{THE CONTRIBUTIONS OF THE LIGHT OF THE WORLD SOCIETY TO C.A.C Evangelism and Church Planting}

The major contribution of the Light of the World Society to the growth of C.A.C was in this aspect. The members were noted for their ceaseless prayers of faith, revival meetings and open air gospel rallies/crusades in different towns and cities in the South Western part of Nigeria. It was the usual practice of the Society to go to strategic places to conduct revival meetings which usually featured house to house evangelism and open air crusades in the neighbourhoods.

The Society held some of its past evangelistic outreaches between 1970 and 1985 in Ibadan (1970), Lagos (1972), Abeokuta (1973), Ile Ife (1974), Ogbomoso (1976), Mushin (1977), Akure (1978), Ijebu 
Ode (1979), Ikirun (1981), Osogbo (1983) and Ilesa (1984). ${ }^{14}$ These evangelistic outreaches led to conversion of souls, spiritual edification of church members and numerical growth of the church. Regular aftermaths of such meetings have been the planting of churches in such communities. ${ }^{15}$

It was also noted that due to the revival fire and the spiritual militancy of the Light of the World Society, many of the Pastors in the Church who engaged in church planting always sought the assistance of the Society whenever they received the divine order to go to a new area to establish a new branch of the church. ${ }^{16}$ Members of the Society always supported the pastors with their physical presence in such places, persistent fervent prayers, house to house evangelism and open air rallies/crusades. ${ }^{17}$

Many of the old C.A.C Assemblies in most parts of Yoruba land were established as a result of the evangelistic activities of this Society. Some of such C.A.C Assemblies are C.A.C Idi Arere (1949), C.A.C Eleta (1949), C.A.C Olugbode, C.A.C Oniyanrin, C.A.C Idikan, C.A.C Agbokojo, C.A.C Olugbode Odo Ona, C.A.C Akufo, C.A.C Oke Ayo, Mokola and C.A.C Oke Isegun, Ode Oolo all in Ibadan. ${ }^{18}$ Others are, C.A.C No. 10, Agbala Itunu, Old Ikirun Road, C.A.C No. 11, Oke Itura, Ota Efun, C.A.C No. 13 Dada Estate, C.A.C No. 18, Temidire, C.A.C No. 19, 'Olorun ko la sin nu', Alekuwodo and C.A.C Temple of the Lord, Ogo Oluwa, all in Osogbo, Osun State and C.A.C No 10 Ajana Street, Lagos.

The active participation of the Society in Evangelism and Church contributed a lot to the physical and numerical growth of the Church in the South Western part of the country.

\section{PROMOTION OF CHRISTIAN EDUCATION}

In order to promote its programmes and reach a wider audience, the Light of the World Society published Christian Education Literature books including tracts and a monthly bulletin titled "The Light of the World" in English and Yoruba languages. ${ }^{19}$ It also has a General Publicity Department that liaised with District Publicity Secretaries in the circulation of the publications. ${ }^{20}$ The publications were regularly distributed nationwide and their circulation contributed to the spiritual enlightenment and growth of church members.

\section{LEADERSHIP DEVELOPMENT}

By leadership development, we mean the development of church manpower in the form of leaders and workers of different categories.
The Light of the World Society, being one of the earliest youth organisations in the church attracted many youths of the Church because of its vibrancy. The spiritual activities of the group via Bible teachings, Mountain top prayer retreats which often include fasting led to accelerated spiritual growth among the members. This spiritual development made the youths to develop into leadership positions in the church. The Society has produced many leaders who have operated in the church as Sunday school teachers, choir members, ushers, juvenile teachers, interpreters, prayer warriors and Pastors. A great number of the members have been appointed into leadership positions and ordained as Pastors, Evangelists and Elders over the years. $^{21}$

Nearly all the middle aged and aged men at the top leadership positions (District Superintendents, District Evangelists, Chairmen of DCC or Zones, Asst. General Superintendents, Asst. General Evangelists, General Superintendent, General Evangelist, General Secretary, and President) in the church today were members of the Light of the World Society during their youthful years. ${ }^{22}$ Some of them were: Late Pastors S. I. Fagbo, Yerokun, Biobaku, M. D. Mogaji, and Babs Mala. Others are: Pastor Adeoye, (Chairman, C.A.C Itire Zone, Lagos), Pastor Egbeola (Ibadan), Pastor Samuel Okewale (Ibadan), Pastor Olusola Yerokun (Ibadan), Pastor Olowoyo (Lagos), Prophet Oni (Ibadan), Pastor Samuel Omodamisi (Ogbomoso), Elder Ajana (Lagos) and a host of many others. ${ }^{23}$

\section{CONCLUSION}

Youths should be encouraged to operate in the church without suspicion and their vision/programmes should be embraced by the leadership of the church. Church leaders must have a positive and respectful view of young people in order to engage them meaningfully for church growth. Negative views of young people tend to limit their opportunities to participate actively in activities that promote church growth and expansion. Church leaders should rather accept and nurtured them gradually to greater heights in life.

Youths must not only be seen as leaders of tomorrow but leaders today. We cannot afford to let them wait until they are older to make important contributions to the life of the church. Their ministry is essential. The things they can do, the places they can go and the impacts they can make are enormous. Their ministry builds the church, reaches the lost, and enhances the continuity of the church. We need them now just as the early church needed them. ${ }^{24}$ 


\section{ENDNOTES}

${ }^{1}$ George Ehusani, "Success Without Successor is Failure in Disguise" A Paper presented at the $1^{\text {st }}$ Nnewi Diocesan Synod. (The Catholic Church, Nigeria, Nnewi Diocese, 2005) pp 210-235.

${ }^{2}$ Deji Ayegboyin, and Ademola Ishola, African Indigenous Churches, (Lagos: Greater Heights Publications, 1997), 10 .

3 Babs Mala, "Christ Apostolic Church: Its Present Preoccupation", in African Independent Churches in the 80s, ed. Babs Mala (Lagos: Organisation of African Instituted Churches, 1983), 67.

4 Adeware Alokan, The Christ Apostolic Church (Nigeria: Ibukunolu Printers Ltd., 1991), 267-273.

5 J. A. Ademakinwa, History of Christ Apostolic Church. (Grand Prairie: Christ Apostolic Church, 2012), 141-154.

${ }^{6}$ Ibid.

${ }^{7}$ Adeware Alokan, The Christ Apostolic Church (Nigeria: Ibukunolu Printers Ltd., 1991), 267-273.

${ }^{8}$ Ibid.

${ }^{9}$ Oluwaremi Festus Adeniji (Pastor), AGE, Interview Respondent. Interviewed on 17/01/14 at C.A.C Oke Agbara Distric HQ, Asi, Ibadan.

${ }^{10}$ C.A.C, The Constitution of the Light of the World Society. (Akure: Duduyemi Commercial Press Ltd., 1988), 5-6.

${ }^{11}$ Ibid 11-24.

${ }^{12}$ Adeware Alokan, The Christ Apostolic Church (Nigeria: Ibukunolu Printers Ltd., 1991), 267-273.

${ }^{13}$ Ibid.

${ }^{14}$ Ibid.

15 Oluwaremi Festus Adeniji (Pastor), AGE, Interview Respondent. Interviewed on 17/01/14 at C.A.C Oke Agbara Distric HQ, Asi, Ibadan

16 Oluwaremi Festus Adeniji (Pastor), AGE, Interview Respondent. Interviewed on 17/01/14 at C.A.C Oke Agbara Distric HQ, Asi, Ibadan

17 Ijitona, David (Pastor), C.A.C Oke Imole Agbowo Zonal $H Q$, Ibadan. Interview Respondent. Interviewed on 17/01/14 at his residence, along Iwo Road - Ojoo Express way, Ibadan

18 Olusola Yerokun (Pastor), Interview Respondent. Interviewed on 14/05/14 at His residence, Alakia, Ibadan.

${ }^{19}$ Adeware Alokan, Christ Apostolic Church at 90. (Ile-Ife: Timade Ventures, 2010), 266-269

${ }^{20}$ Ibid.

21 S. I. Fagbo (A.G.E.), Presidential Address at the $20^{\text {th }}$ Annual National Rally of Light of the World Society in 1990.

Okewale, Samuel (Pastor), Interview Respondent. Interviewed on 29/05/2014 at District HQ, CAC Oke Alaafia, Loyola, Old Ife Road, Ibadan.

${ }^{22}$ Adeoye (Pastor), AGS, Interview Respondent. Interviewed on 16/05/14 at C.A.C Lodge Street, Oke Ado, Ibadan.
23 Okewale, Samuel (Pastor), Interview Respondent. Interviewed on 29/05/2014 at District HQ, CAC Oke Alaafia, Loyola, Old Ife Road, Ibadan.

${ }^{24}$ O. P. Ademola. 1994. The Youths in Nation Building: A Case Study of Nigerian Baptist Convention Youth Organisations. A M.A Dissertation in Department of Religious Studies, University of Ibadan. 5. 